Al-Masharif: Jurnal Ilmu Ekonomi dan Keislaman

Volume 6 Nomor 1 Ed. Januari-Juni 2018 : hal. 106-127

p-ISSN: 2356-4628 e-ISSN : 2579-8650

\title{
FAKTOR-FAKTOR YANG MEMPENGARUHI INDEKS PEMBANGUNAN MANUSIA (IPM) DI PROVINSI SUMATERA UTARA TAHUN 1995-2014".
}

\author{
Rosnani Siregar, Nurul Izzah, Siti Muninggar \\ IAIN Padangsidimpuan \\ Jalan T. Rizal Nurdin Km. 4,5 Sihitang, Padangsidimpuan \\ Email : zulaikamatondang83@gmail.com
}

\begin{abstract}
Abstrak,
Penelitian ini dilakukan dengan tujuan untuk mengetahui faktor-faktor yang mempengaruh indeks pembangunan manusia (IPM) di provinsi sumatera utara tahun 1995-2014. Penelitian ini merupakan penelitian kuantitatif dengan menggunakan metode analisis regresi berganda. Teknik pengumpulan data yang digunakan adalah data sekunder yang bersumber dari publikasi Badan Pusat Statistik Sumatera Utara. Sampel yang digunakan sebanyak 20 data pertahun. Hasil dari penelitian ini adalah pertumbuhan ekonomi (X1) tidak berpengaruh signifikan terhadap IPM dimana thitung (0,1304)> alpha (0,05), kemiskinan (X2) tidak berpengaruh signifikan terhadap IPM dimana thitung $(0,3076)>$ alpha $(0,05)$, dan pengeluaran pemerintah berpengaruh signifikan terhadap IPM dengan thitung $(0,0026)<$ alpha $(0,05)$. Variabel pertumbuhan ekonomi (X1), kemiskinan (X2), dan pengeluaran pemerintah ( $\left.\mathrm{X}_{3}\right)$ secara bersama-sama mempunyai pengaruh yang signifikan terhadap variabel IPM (Y) terlihat dari Fhitung (0.005144) $<F_{\text {tabel }}(3.13)$. Koefisien determinan $\left(\mathrm{R}^{2}\right)$ sebesar 0,539971 artinya bahwa variabel pertumbuhan ekonomi, kemiskinan, dan pengeluaran pemerintah mampu menjelaskan variabel IPM sebesar 53,99 persen. Sedangkan sisanya sebesar 46,01 persen dijelaskan oleh variabel lain diluar model. Dalam artian masih terdapat variabel lain yang mempengaruhi Indeks Pembangunan Manusia (IPM) selain variabel pertumbuhan ekonomi, kemiskinan, dan pengeluaran pemerintah.
\end{abstract}

Kata Kunci: PertumbuhanEkonomi, Kemiskinan, PengeluaranPemerintah, dan IPM.

\begin{abstract}
,
This research was conducted with the aim to determine the factors that influence the human development index (HDI) in North Sumatra province in 1995-2014. This research is a quantitative study using multiple regression analysis. The data collection technique used is secondary data sourced from the publication of the Central Sumatra Statistics Agency. The sample used was 20 data per year. The results of this study are economic growth (X1) does not have a significant effect on HDI where tcount (0.1304)> alpha (0.05), poverty (X2) does not significantly influence the HDI where tcount $(0.3076)>$ alpha $(0,05)$, and government expenditure has a significant effect on the HDI with tcount $(0.0026)<$ alpha (0.05). The variables of economic growth (X1), poverty (X2), and government expenditure (X3) together have a significant effect on the HDI variable (Y) seen from Fcount (0.005144) <Ftable (3.13). The determinant coefficient (R2) of 0.539971 means that the variables of economic growth, poverty, and government expenditure are able to explain the HDI variable of 53.99 percent. While the remaining 46.01 percent is explained by other variables outside the model. In the sense that there are still other variables that affect the Human Development Index (HDI) in addition to the variables of economic growth, poverty, and government expenditure.
\end{abstract}




\section{FAKTOR-FAKTOR YANG MEMPENGARUHI INDEKS PEMBANGUNAN MANUSIA (IPM) DI PROVINSI SUMATERA UTARA TAHUN 1995-2014"}

Keywords: Economic Growth, Poverty, Government Expenditures, and HDI

\section{PENDAHULUAN}

Salah satu indikator yang membedakan antara negara maju dengan negara berkembang adalah Indeks Pembangunan Manusia (IPM). Angka Indeks Pembangunan Manusia (IPM), mencakup tiga komponen dasar yang mengukur kualitas hidup manusia yaitu angka harapan hidup pada waktu lahir (life expectancy at birth), angka melek huruf (literacy rate) dan rata-rata lama sekolah (mean years of schooling), dan kemampuan daya beli (purchasing power parity). Indikator angka harapan hidup mengukur kesehatan, indikator angka melek huruf penduduk dewasa dan rata-rata lama sekolah mengukur pendidikan, dan terakhir indikator daya beli mengukur standar hidup. Perkembangan Indeks Pembangunan Manusia (IPM) di Sumatera Utara dapat dilihat pada tabel dibawah ini :

Tabel 1.1 Perkembangan Indeks Pembangunan Manusia (IPM) di Provinsi Sumatera Utara Tahun 1995-2014

\begin{tabular}{|c|c|}
\hline Tahun & Indeks Pembangunan Manusia (IPM) (\%) \\
\hline 1995 & 70,23 \\
\hline 1996 & 70,50 \\
\hline 1997 & 70,51 \\
\hline 1998 & 70,53 \\
\hline 1999 & 66,60 \\
\hline 2000 & 66,42 \\
\hline 2001 & 80,50 \\
\hline 2002 & 68,80 \\
\hline 2003 & 70,50 \\
\hline 2004 & 71,40 \\
\hline 2005 & 72,03 \\
\hline 2006 & 72,46 \\
\hline 2007 & 72,78 \\
\hline 2008 & 73,29 \\
\hline 2009 & 73,80 \\
\hline 2010 & 74,19 \\
\hline 2011 & 74,65 \\
\hline 2012 & 75,13 \\
\hline 2013 & 75,55 \\
\hline 2014 & 68,87 \\
\hline
\end{tabular}

Sumber : BPS Sumatera Utara 
Tabel 1.1 diatas pada periode tahun 1995-2014 mengalami fluktuasi pada tahun 2006 Indeks Pembangunan Manusia (IPM) meningkat sebesar 0,59 persen, dan setiap tahunnya meningkat hingga ke tahun 2013. Indeks Pembangunan Manusia (IPM) paling tinggi terjadi pada tahun 2001 mencapai 21,19 persen dan kemudian menurun pada tahun 2014 sebesar 6,68 persen.

Keseimbangan pertumbuhan ekonomi dengan pembangunan manusia merupakan salah satu hal yangsaling berkaitan dan harus searah agar tercipta keberhasilan pembangunan.Modal manusia (human capital) merupakan salah satu faktor penting dalam proses pertumbuhan ekonomi. Oleh karena itu dalam rangka memicu pertumbuhan ekonomi perlu dilakukan pembangunan manusia. Selain itu, capaian pertumbuhan ekonomi yang semakin membaik dengan diimbangi distribusi pendapatan yang merata dan alokasi belanja publik yang memadai untuk pendidikan dan kesehatan dapat diinvestasikan untuk pembangunan manusia. Berikut perkembangan pertumbuhan ekonomi di provinsi Sumatera Utara tahun 1995-2014.

Tabel 1.2 Perkembangan PDRB Atas Dasar Harga Konstan 2000 Tahun 1995-2014 (Miliar Rupiah)

\begin{tabular}{|c|c|c|}
\hline Tahun & PDRB & $\begin{array}{l}\text { Laju Pertumbuhan } \\
\text { Ekonomi(\%) }\end{array}$ \\
\hline 1995 & 64.753 .80 & - \\
\hline 1996 & 67.714 .73 & 4,57 \\
\hline 1997 & 68.065 .40 & 0,51 \\
\hline 1998 & 66.332 .68 & $-2,54$ \\
\hline 1999 & 68.910 .08 & 3,88 \\
\hline 2000 & 71.116 .21 & 0,35 \\
\hline 2001 & 71.908 .35 & 3,98 \\
\hline 2002 & 75.189 .50 & 4,56 \\
\hline 2003 & 78.806 .68 & 4,80 \\
\hline 2004 & 83.328 .94 & 5,73 \\
\hline 2005 & 87.897 .79 & 5,48 \\
\hline 2006 & 93.347 .40 & 6,19 \\
\hline 2007 & 99.792 .27 & 6,90 \\
\hline 2008 & 106.172 .36 & 6,39 \\
\hline 2009 & 111.559 .22 & 5,07 \\
\hline 2010 & 118.640 .90 & 6,34 \\
\hline 2011 & 126.590 .21 & 6,70 \\
\hline 2012 & 134.460 .10 & 6,22 \\
\hline 2013 & 142.537 .12 & 6,00 \\
\hline 2014 & 149.991 .81 & 5,05 \\
\hline
\end{tabular}

Sumber : BPS Sumatera Utara 


\section{FAKTOR-FAKTOR YANG MEMPENGARUHI INDEKS PEMBANGUNAN MANUSIA (IPM) DI PROVINSI SUMATERA UTARA TAHUN 1995-2014"}

Tabel 1.2 diatas periode 1995-2014 Produk Domestik Regional Bruto (PDRB) dari tahun ke tahun cenderung mengalami peningkatan. Pada tahun 1998 Produk Domestik Regional Bruto (PDRB) mengalami penurunan sebesar 2,54 persen yang diakibatkan terjadinya krisis ekonomi tahun 1998. Selanjutnya PDRB terus meningkat hingga tahun 2014 telah mencapai Rp. 152.782.22 miliar.

Pertumbuhan ekonomi dan Indeks Pembangunan Manusia (IPM) memiliki hubungan yang positif sehingga semakin tinggi tingkat pertumbuhan ekonomi maka Indeks Pembangunan Manusia (IPM) juga ikut meningkat dan sebaliknya. Namun berdasarkan data yang dipaparkan diatas pada periode tahun 1995-2014 peningkatan pertumbuhan ekonomi tidak diikuti dengan peningkatanIndeks Pembangunan Manusia(IPM) dilihat pada tahun 1995, 1999, 2000, dan tahun 2014. Pada beberapa tahun tersebut, Indeks Pembangunan Manusia (IPM) menurun ketika pertumbuhan ekonomi mengalami peningkatan.

Berdasarkan data yang dipaparkan sebelumnya, menunjukkan Indeks Pembangunan Manusia (IPM) tidak selalu mengalami peningkatan dari tahun ke tahun. Dengan demikian, bahwa perkembangan pertumbuhan ekonomi tidak sejalan dengan perkembangan Indeks Pembangunan Manusia (IPM).

Selain pertumbuhan ekonomi, kemiskinan merupakan salah satu masalah penting yang dihadapi pemerintah yang mempengaruhi pembangunan manusia di provinsi Sumatera Utara.Perkembangan penduduk miskin di provinsi Sumatera Utara dari tahun ke tahun mengalami kenaikan dan penurunan sehinggadiperlukan beberapa program guna meminimalisasi tingkat fluktuasinya dan dengan demikian pembangunan manusia dapat lebih stabil.Kemiskinan dapat menjadikan efek yang cukup serius bagi pembangunan manusia karena masalah kemiskinan merupakan masalah yang kompleks yang sebenarnya bermula dari kemampuan daya beli masyarakat yang tidak mampu untuk mencukupi kebutuhan pokoknya sehingga kebutuhan yang lain seperti kesehatan dan pendidikan pun terabaikan. Adapun perkembangan penduduk miskin di provinsi Sumatera Utara dapat dilihat dari Tabel 1.3 berikut ini 
Tabel 1.3 Perkembangan Persentase Penduduk Miskin Provinsi Sumatera UtaraPada Tahun 1995-2014

\begin{tabular}{|c|c|c|}
\hline Tahun & Jumlah Penduduk Miskin (Jiwa) & $\begin{array}{c}\text { Persentase Penduduk Miskin } \\
\text { (\%) }\end{array}$ \\
\hline 1995 & 3.439 .020 & - \\
\hline 1996 & 1.234 .194 & $-64,11$ \\
\hline 1997 & 1.836 .203 & 48,77 \\
\hline 1998 & 3.550 .642 & $93 \cdot 36$ \\
\hline 1999 & 1.972 .700 & $-44,44$ \\
\hline 2000 & 1.199 .900 & $-39,17$ \\
\hline 2001 & 1.541 .895 & 28,50 \\
\hline 2002 & 1.883 .890 & 22.18 \\
\hline 2003 & 1.889 .400 & 0,29 \\
\hline 2004 & 1.800 .100 & $-4,72$ \\
\hline 2005 & 1.760 .228 & $-2,21$ \\
\hline 2006 & 1.979 .702 & 12,46 \\
\hline 2007 & 1.768 .500 & $-10,66$ \\
\hline 2008 & 1.613 .800 & $-8,74$ \\
\hline 2009 & 1.499 .700 & $-7,07$ \\
\hline 2010 & 1.490 .900 & $-0,58$ \\
\hline 2011 & 1.481 .300 & $-0,64$ \\
\hline 2012 & 1.407 .200 & $-5,00$ \\
\hline 2013 & 1.339 .200 & $-4,83$ \\
\hline 2014 & 1.286 .700 & $-3,92$ \\
\hline
\end{tabular}

Sumber : BPS Sumatera Utara

Tabel 1.3 diatas menunjukkan bahwa perkembangan persentase penduduk miskin di provinsi Sumatera Utara selama kurun waktu mulai dari tahun 1995-2014 mengalami kenaikan dan penurunan. Pada tahun 1997 persentase penduduk miskin sebesar 48,77 persen dan pada tahun 1998 jumlah penduduk miskin mengalami peningkatan sebesar 93,36 persen dari tahun sebelumnya. Hal ini disebabkan oleh krisis ekonomi yang terjadi pada tahun 1998. Kemiskinan dan Indeks Pembangunan Manusia (IPM) memiliki hubungan negatif jika kemiskinan menurun maka Indeks Pembangunan Manusia (IPM) akan mengalami peningkatan.

Berdasarkan data yang diperoleh pada periode 1995-2014 ketika kemiskinan meningkat Indeks Pembangunan Manusia (IPM) juga ikut meningkat. Hal ini terjadi pada tahun 2001, 2003, dan tahun 2006. Berdasarkan data yang telah dijelaskan sebelumnya, menunjukkan Indeks Pembangunan Manusia (IPM) dari tahun ke tahun tidak selalu meningkat. Sehingga dapat diambil kesimpulan bahwa perkembangan tingkat kemiskinan tidak sejalan dengan perkembangan Indeks Pembangunan Manusia (IPM). 


\section{FAKTOR-FAKTOR YANG MEMPENGARUHI INDEKS PEMBANGUNAN MANUSIA (IPM) DI PROVINSI SUMATERA UTARA TAHUN 1995-2014"}

Pengeluaran pemerintah dapat digunakan sebagai cerminan kebijakan yang di ambil oleh pemerintah dalam suatu wilayah. Kebijakan pemerintah dalam tiap pembelian barang dan jasa guna pelaksanaan suatu program mencerminkan besarnya biaya yang akan dikeluarkan pemerintah untuk melaksanakan program tersebut. Perkembangan pengeluaran pemerintah dapat dilihat melalui Tabel 1.4berikut ini:

Tabel 1.4 Perkembangan Pengeluaran Pemerintah Provinsi Sumatera UtaraPada Tahun 1995-2014

\begin{tabular}{|c|c|}
\hline Tahun & Pengeluaran Pemerintah (Miliar Rupiah) \\
\hline 1995 & 515.600 .000 \\
\hline 1996 & 584.000 .000 \\
\hline 1997 & 660.800 .000 \\
\hline 1998 & 1.298 .900 .000 \\
\hline 1999 & 1.666 .700 .000 \\
\hline 2000 & 1.614 .200 .000 \\
\hline 2001 & 3.852 .000 .000 \\
\hline 2002 & 4.829 .300 .000 \\
\hline 2003 & 6.290 .100 .000 \\
\hline 2004 & 6.081 .400 .000 \\
\hline 2005 & 6.907 .600 .000 \\
\hline 2006 & 8.409 .600 .000 \\
\hline 2007 & 13.648 .100 .000 \\
\hline 2008 & 3.009 .521 .195 \\
\hline 2009 & 3.476 .698 .496 \\
\hline 2010 & 3.827 .284 .878 \\
\hline 2011 & 4.642 .394 .869 \\
\hline 2012 & 7.898 .946 .506 \\
\hline 2013 & $7 \cdot 360.668 .253$ \\
\hline 2014 & 7.808 .557 .310 \\
\hline
\end{tabular}

Sumber : BPS Sumatera Utara

Tabel 1.4 diatas periode 1995-2014 pengeluaran pemerintah dari tahun ketahun mengalami peningkatan. Selama periode tersebut, pengeluaran pemerintah di Sumatera Utara hanya empat kali mengalami penurunan yaitu pada tahun 2000 pengeluaran pemerintah turun sebesar 3,14 persen dari tahun sebelumnya. Pada tahun 2004 pengeluaran pemerintah turun menjadi Rp. 6.081.400.000 miliar, kemudian pada tahun 2008 pengeluaran pemerintah turun sebesar 77,94 persen dan pada tahun 2013 kembali mengalami penurunan sebesar 6,81 persen. 
Peningkatan pengeluaran pemerintah disebabkan karena salah satu upaya yang dilakukan oleh pemerintah saat ini adalah meningkatkan kesejahteraan melalui pemberian pendidikan dan kesehatan bagi masyarakat yang kurang mampu. Sementara rendahnya pengeluaran pemerintah akan mempengaruhi kualitas sumberdaya manusia khususnya dikedua sektor ini. Mengingat kesehatan merupakan inti dari kesejahteraan dan pendidikan adalah hal pokok untuk mencapai kehidupan yang layak.

Berdasarkan latar belakang masalah dan fenomena tersebut, penulis tertarik untuk melakukan penelitian mengenai: 'Faktor-faktor yang Mempengaruhi Indeks Pembangunan Manusia (IPM) di Provinsi Sumatera Utara Tahun 19952014”.

\section{TINJAUAN TEORITIK}

\section{Indeks Pembangunan Manusia}

Manusia adalah kekayaan bangsa yang sesungguhnya. Tujuan utama pembangunan adalah menciptakan lingkungan yang memungkinkan rakyat menikmati umur panjang, sehat, dan menjalankan kehidupan yang produktif (UNDP, Human Development Report 2000). Pembangunan manusia menempatkan manusia sebagai tujuan akhir dari pembangunan bukan alat dari pembangunan.Keberhasilan pembangunan manusia dapat dilihat dari seberapa besar permasalahan mendasar di masyarakat dapat teratasi.Permasalahan-permasalahan tersebut meliputi kemiskinan, pengangguran, gizi buruk, dan buta huruf (Badan Pusat Statistik, 2009).

Modal manusia (human capital) adalah istilah yang sering digunakan oleh para ekonom untuk pendidikan, kesehatan, dan kapasitas manusia yang lain yang dapat meningkatkan produktivitas jika hal-hal tersebut ditingkatkan. Pendidikan dan kesehatan merupakan tujuan pembangunan yang mendasar terlepas dari hal-hal yang lain, kedua hal itu merupakan hal yang penting. Kesehatan merupakan inti dari kesejahteraan, dan pendidikan adalah hal yang pokok untuk menggapai kehidupan yang memuaskan dan berharga, keduanya adalah hal yang fundamental untuk membentuk kapabilitas manusia yang lebih luas yang berada pada inti makna pembangunan (Michael P. Todaro dan Stephen C. Smith, 2003).

Lebih jauh, Human Development Index (HDI) menunjukkan dengan jelas bahwa kesenjangan dalam pendapatan lebih besar daripada kesenjangan dalam indikator 


\section{FAKTOR-FAKTOR YANG MEMPENGARUHI INDEKS \\ PEMBANGUNAN MANUSIA (IPM) DI PROVINSI \\ SUMATERA UTARA TAHUN 1995-2014"}

pembangunan yang lain, paling tidak dalam indikator kesehatan dan pendidikan. Human

Development Index (HDI) juga mengingatkan kita bahwa pembangunan, yang kita maksud adalah pembangunan manusia dalam arti luas, bukan hanya dalam bentuk pendapatan yang lebih tinggi.Banyak negara, seperti sejumlah negara penghasil minyak yang berpendapatan tinggi, disebut sebagai negara yang mengalami "pertumbuhan tanpa pembangunan". Kesehatan dan pendidikan bukan hanya input fungsi produksi (seperti dalam perannya sebagai komponen modal manusia) namun juga merupakan tujuan pembangunan yang fundamental (Michael P. Todaro dan Stephen C. Smith, 2003).

IPM (Indeks Pembangunan Manusia) adalah suatu indeks yang mengukur pembangunan sosial ekonomi suatu daerah berdasarkan pada pengukuran ekonomi, kesehatan, dan pendidikan.Salah satu keunggulan IPM sebagai alat ukur indikator pembangunan adalah fleksibel dalam pengaplikasiannya (Michael P. Todaro dan Stephen C. Smith, 2003).

Indeks Pembangunan Manusia (IPM) juga digunakan untuk melakukan pemeringkatan terhadap kinerja pembangunan berbagai negara di dunia. Berdasarkan indeks IPM-nya, negara-negara di dunia ini dikelompokkan menjadi tiga yaitu:

a. Kelompok negara dengan tingkat pembangunan manusia yang rendah (low human development), bila memiliki nilai Indeks Pembangunan Manusia (IPM) antara 0 sampai 0,50 .

b. Kelompok negara dengan tingkat pembangunan manusia menengah (medium human development), bila memiliki nilai Indeks Pembangunan Manusia (IPM) antara 0,50 sampai 0,79 .

c. Kelompok negara dengan tingkat pembangunan manusia yang tinggi (high human development), bila memiliki nilai Indeks Pembangunan Manusia (IPM) antara 0,79 sampai 1 (Lincolin Arsyad, 2010). 


\section{Pertumbuhan Ekonomi}

Simon Kuznets mendefinisikan pertumbuhan ekonomi sebagai kenaikan jangka panjang dalam kemampuan suatu negara untuk menyediakan semakin banyak jenis barangbarang ekonomi kepada penduduknya. Kemampuan ini tumbuh sesuai dengan kemajuan teknologi, danpenyesuaian kelembagaan dan ideologis yang diperlukannya (M. L. Jhingan, 1996). Pendapat Smith mengenai corak pertumbuhan ekonomi mengatakan bahwa apabila pembangunan sudah terjadi, maka proses tersebut akan terus menerus berlangsung secara kumulatif. Apabila pasar berkembang, pembagian kerja dan spesialisasi kerja akan terjadi dan belakangan akan menimbulkan kenaikan produktivitas.Kenaikan pendapatan nasional yang disebabkan oleh perkembangan tersebut dan perkembangan penduduk, akan memperluas pasar dan menciptakan tabungan yang lebih besar (Sadono Sukirno, 2014). Pendapat ini berbeda dengan pandangan Adam Smith yang menyatakan pertambahan populasi akan menambah pasar. Ricardo dan Mill berpendapat pertumbuhan penduduk yang cepat akan menyebabkan tingkat pembangunan kembali turun ke taraf yang lebih rendah. Pada tingkat ini, pekerja akan menerima upah yang rendah (Sadono Sukirno, 2014).

\section{Pertumbuhan Ekonomi Dalam Islam}

Dalam Islam, pertumbuhan ekonomi memiliki arti berbeda. Pertumbuhan ekonomi harus berlandaskan nilai-nilai iman, takwa, dan konsistensi serta ketekunan untuk melepaskan segala nilai-nilai kemaksiatan dan perbuatan dosa.Hal tersebut tidak di menafikan eksistensi usaha dan pemikiran untuk mengejar segala ketertinggalan dan keterbelakangan yang disesuaikan dengan prinsip syariah (Said Sa'ad Marthon, 2004). Konsep pertumbuhan ekonomi dapat digambarkan dalam Al-Qur'an surah Huud ayat 61 sebagai berikut:

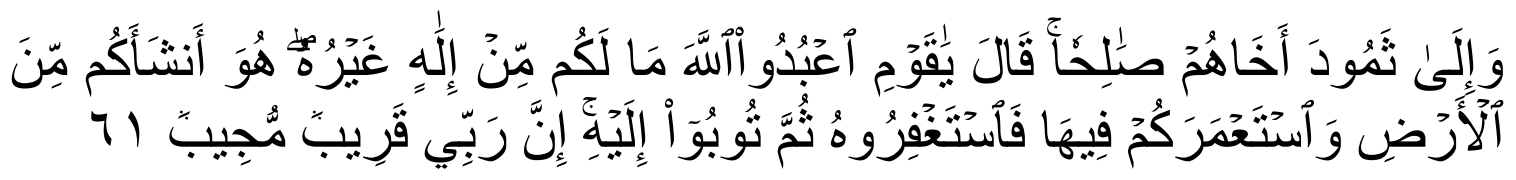




\section{FAKTOR-FAKTOR YANG MEMPENGARUHI INDEKS PEMBANGUNAN MANUSIA (IPM) DI PROVINSI SUMATERA UTARA TAHUN 1995-2014"}

Artinya: dan kepada Tsamud (kami utus) saudara mereka shaleh. Shaleh berkata: "Hai kaumku, sembahlah Allah, sekali-kali tidak ada bagimu Tuhan selain Dia. Dia telah menciptakan kamu dari bumi (tanah) dan menjadikan kamu pemakmurnya, karena itu mohonlah ampunan-Nya, kemudian bertobatlah kepada-Nya, Sesungguhnya Tuhanku Amat dekat (rahmat-Nya) lagi memperkenankan (doa hamba-Nya)."(Departemen Agama RI, 2009)

Lafadz Imarahdalam ayat tersebut, bermakna pertumbuhan atau kebangkitan masyarakat dalam segala aspek kehidupan, dan inilah yang dimaksud dengan pertumbuhan ekonomi.Imarahdimaksudkan bukan hanya sekedar mengejar pertumbuhan materi, tetapi mencakup nilai-nilai spiritual, yaitu beribadah kepada Allah (said Sa'ad Marthon, 2004).

\section{Kemiskinan Menurut Padangan Islam}

Islam sangat membenci sifat meminta-minta (mengemis), dan memerintahkan supaya tiap-tiap muslim untuk menjauhinya, sebab tangan diatas yang memberi, lebih baik daripada tangan dibawa yang menerima (meminta). Nabi Muhammad SAW pernah memberikan uang sedirham kepada orang yang meminta-minta dan menyuruhnya untuk dibelikan kampak dan tali, agar dia dapat mencari kayu, sehingga dia tidak hidup dengan cara meminta-minta yang sangat hina tersebut (Abdullah Zaky Al Kaaf, 2002).

Islam mendorong umatnya untuk dapat memperoleh penguasaan atas seluruh alam, sebab menurut Al-Qur'an, seluruh sumber daya di langit dan di bumi telah Allah ciptakan untuk kemakmuran manusia. Tekanan islam disini adalah pada kesejahteraan ekonomi yang berasal dari seluruh alam dan isinya. Islam dirancang sebagai suatu berkat untuk kesejahteraan hidup manusia, yang mengarahkan hidup lebih kaya dan menghargai kehidupan dan bukan lebih miskin, penuh dengan kesukaran dan penderitaan, sebagaimana firman Allah dalam surat An-nisa' ayat 9:

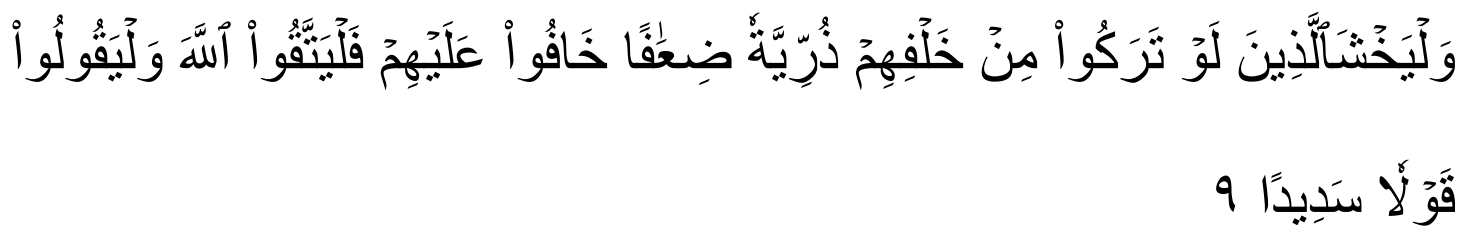


Artinya: "Dan hendaklah takut kepada Allah orang-orang yang seandainya meninggalkan dibelakang mereka anak-anak yang lemah, yang mereka khawatir terhadap (kesejahteraan) mereka. Oleh sebab itu hendaklah mereka bertakwa kepada Allah dan hendaklah mereka mengucapkan perkataan yang benar”. (Q.S An-nisa': 9) (Departemen Agama RI, 2009)

Dalam ayat diatas, Allah menganjurkan kepada manusia untuk memperhatikan generasi penerusnya (anak keturunannya) agar tidak terjatuh dalam kondisi kemiskinan, hal itu bisa dilakukan dengan mempersiapkan atau mendidik generasi penerusnya (anak keturunannya) dengan pendidikan yang berkualitas dan berorientasi pada kesejahteraan moral dan material, sehingga kelak menjadi SDM yang terampil dan berakhlakul kharimah, mengingat anak adalah asset yang termahal bagi orang tua (Amirus Sodiq, 2015).

\section{Pengeluaran Pemerintah}

Berdasarkan atas penilaian ini kita dapat membedakan bermacam-macam pengeluaran negara seperti:

1. Pengeluaran yang "self-liquiditing" sebagian atau seluruhnya, artinya pengeluaran pemerintah mendapatkan pembayaran kembali dari masyarakat yang menerima jasa-jasa/barang-barang yang bersangkutan.

2. Pengeluaran yang reproduktif, artinya mewujudkan keuntungan-keuntungan ekonomis bagi masyarakat, yang dengan naiknya tingkatan penghasilan dan sasaran pajak yang lain akhirnyaakan menaikkan penerimaan pemerintahan.

3. Pengluaran yang tidak "self-liquiditing" maupun yang tidak reproduktif yaitu pengeluaran yang langsung menambahkan kegembiraan dan kesejahteraan masyarakat misalnya untuk bidang-bidang rekreasi, pendirian monument, obyekobyek tourisme, dan sebagainya.

4. Pengeluaran yang secara langsung tidak produktif dan merupakan pemborosan misalnya untuk pembiayaan pertahanan/perang meskipun pada saat pengeluaran terjadi penghasilan perorangan yang menerimanya akan naik. 


\section{FAKTOR-FAKTOR YANG MEMPENGARUHI INDEKS \\ PEMBANGUNAN MANUSIA (IPM) DI PROVINSI \\ SUMATERA UTARA TAHUN 1995-2014"}

5. Pengeluaran yang merupakan penghematan dimasa yang akan datang misalnya pengeluaran untuk anak-anak yatim piatu Suparmoko, 2000).

\section{Hipotesis}

Hipotesis merupakan kesimpulan teoritis atau sementara dalam penelitian. Hipotesis merupakan hasil akhir dari proses berpikir deduktif (logika deduktif). Logika deduktif adalah menganut koherensi, mengingat premis merupakan informasi yang bersumber dari pernyataan yang telah teruji kebenarannya, maka hipotesis yang akan dirumuskan akan mempunyai derajat kebenaran yang tidak jauh berbeda dari premis (Muhammad, 2008).

Berdasarkan rumusan masalah yang sebagaimana telah diuraikan maka yang menjadi hipotesis yaitu sebagai berikut:

$\mathrm{H}_{01}=$ Pertumbuhan ekonomi tidak berpengaruh terhadap Indeks Pembangunan Manusia (IPM) di Provinsi Sumatera Utara tahun 1995-2014.

$\mathrm{H}_{\mathrm{a} 1}=$ Pertumbuhan ekonomi berpengaruh terhadap Indeks Pembangunan Manusia (IPM) di Provinsi Sumatera Utara tahun 1995-2014.

$\mathrm{H}_{02}=$ Tingkat kemiskinan tidak berpengaruhterhadap Indeks Pembangunan Manusia(IPM) di Provinsi Sumatera Utara tahun 1995-2014.

$\mathrm{H}_{\mathrm{a} 2}=$ Tingkat kemiskinan berpengaruhterhadapIndeks Pembangunan Manusia(IPM) di Provinsi Sumatera Utara tahun 1995-2014.

$\mathrm{H}_{03}=$ Pengeluaran pemerintah tidak berpengaruh terhadap Indeks Pembangunan Manusia(IPM) di Provinsi Sumatera Utara tahun 1995-2014.

$\mathrm{H}_{\mathrm{a} 3}=$ Pengeluaran pemerintah berpengaruh terhadapIndeks Pembangunan Manusia(IPM) di Provinsi Sumatera Utara tahun 1995-2014.

$\mathrm{H}_{04}=$ Pertumbuhan ekonomi, tingkat kemiskinan, dan pengeluaran pemerintah tidak berpengaruh terhadap Indeks Pembangunan Manusia(IPM) di Provinsi Sumatera Utara tahun 1995-2014. 
$\mathrm{H}_{\mathrm{a} 4}=$ Pertumbuhan ekonomi, tingkat kemiskinan, dan pengeluaran pemerintah berpengaruhterhadapIndeks Pembangunan Manusia(IPM) di Provinsi Sumatera Utara tahun 1995-2014.

\section{METODE PENELITIAN}

Persamaan regresi linier berganda yang digunakan dalam penelitian ini adalah :

$$
\mathrm{IPM}=\beta_{0}+\beta_{1} \mathrm{PE}+\beta_{2} \mathrm{TK}+\beta_{3} \mathrm{PP}+\mathrm{e}
$$

$$
\begin{aligned}
& \text { Keterangan : } \\
& \text { IPM } \quad=\text { Indeks Pembangunan Manusia (IPM) } \\
& \beta_{0} \quad=\text { Konstanta } \\
& \mathrm{PE} \quad=\text { PertumbuhanEkonomi } \\
& \mathrm{TK} \quad=\text { Tingkat Kemiskinan } \\
& \mathrm{PP} \quad=\text { PengeluaranPemerintah } \\
& \beta_{1} \beta_{2} \beta_{3} \quad=\text { Koefisien } \\
& \mathrm{e} \quad=\text { Error }
\end{aligned}
$$

\section{Pengujian Asumsi Klasik}

Uji asumsi klasik digunakan untuk menguji normalitas data penelitian, uji multokilinearitas, uji heteroskedastisitas dan uji autokorelasi. Menurut (Sugiono dan Susanto, 2015), uji normalitas bertujuan untuk menguji data penelitian baik variabel dependen maupun variabel independen terdistribusi normal atau tidak dengan menggunakan kolmogrov-smirnow pada taraf signifikan 0,05. Dan uji multikolinieritas digunakan untuk melihat adanya hubungan linier sempurna diantara variabel independennya dengan melihat nilai VIF (Variance Inflasion Factor). Dan uji heteroskedastisitas digunakan untuk mengetahui ada atau tidaknya penyimpangan asumsi klasik melalui penyebaran titik yang tidak membentuk pola. Dan mengukur uji autokorelasi dengan melihat hasil uji Durbin-Watson (DW).

\section{Pengujian Hipotesis}

Uji hipotesis digunakan untuk mengukur besarnya pengaruh variabel independen terhadap variabel dependen. Untuk mengukur seberapa jauh kemampuan model dalam 


\section{FAKTOR-FAKTOR YANG MEMPENGARUHI INDEKS \\ PEMBANGUNAN MANUSIA (IPM) DI PROVINSI \\ SUMATERA UTARA TAHUN 1995-2014"}

menerangkan variasi dependen digunakan uji koefisien determinasi $\left(\mathrm{R}^{2}\right)$, menurut (Setiawan dan Kusrini, 2010), nilai yang mendekati satu berarti variabel-variabel independen memberikan hampir semua informasi yang dibutuhkan untuk memprediksi variasi variabel dependen. Untuk mengetahui apakah ada model regresi variabel independen secara parsial berpengaruh signifikan terhadap variabel dependen, maka digunakanlah uji $t$, menurut (Siregar, 2014), kaidah pengujian untuk menguji secara parsial yaitu jika $T_{\text {hitung }} \leq \mathrm{T}_{\text {tabel }}$ maka $\mathrm{H}_{\mathrm{o}}$ diterima dan $\mathrm{H}_{\mathrm{a}}$ ditolak, dan jika $\mathrm{T}_{\text {hitung }} \geq \mathrm{T}_{\text {tabel }}$ maka $\mathrm{H}_{\mathrm{o}}$ ditolak dan $\mathrm{H}_{\mathrm{a}}$ diterima. Dan untuk mengetahui pengaruh semua variabel independen terhadap variabel dependen maka digunakanlah uji $\mathrm{F}$, uji ini dilakukan dengan syarat bila $\mathrm{F}_{\text {hitung }}<\mathrm{F}_{\text {tabel }}$ maka $\mathrm{H}_{\mathrm{o}}$ diterima dan $\mathrm{H}_{\mathrm{a}}$ ditolak, bila $\mathrm{F}_{\text {hitung }}>\mathrm{F}_{\text {tabel }}$ maka $\mathrm{H}_{\mathrm{o}}$ ditolak dan $\mathrm{H}_{\mathrm{a}}$ diterima.

\section{HASIL DAN PEMBAHASAN}

Populasi dalam penelitian ini adalah seluruh data pertumbuhan ekonomi, tingkat kemiskinan, pengeluaran pemerintah dan Indeks Pembangunan Manusia di Provinsi Sumatera Utara tahun 1995-2014. Sebelum melakukan analisis data, terlebih dahulu menentukan uji normalitas dari data penelitian, adapun hasil uji normalitas penelitian ini adalah :

Tabel 1

Hasil Uji Normalitas

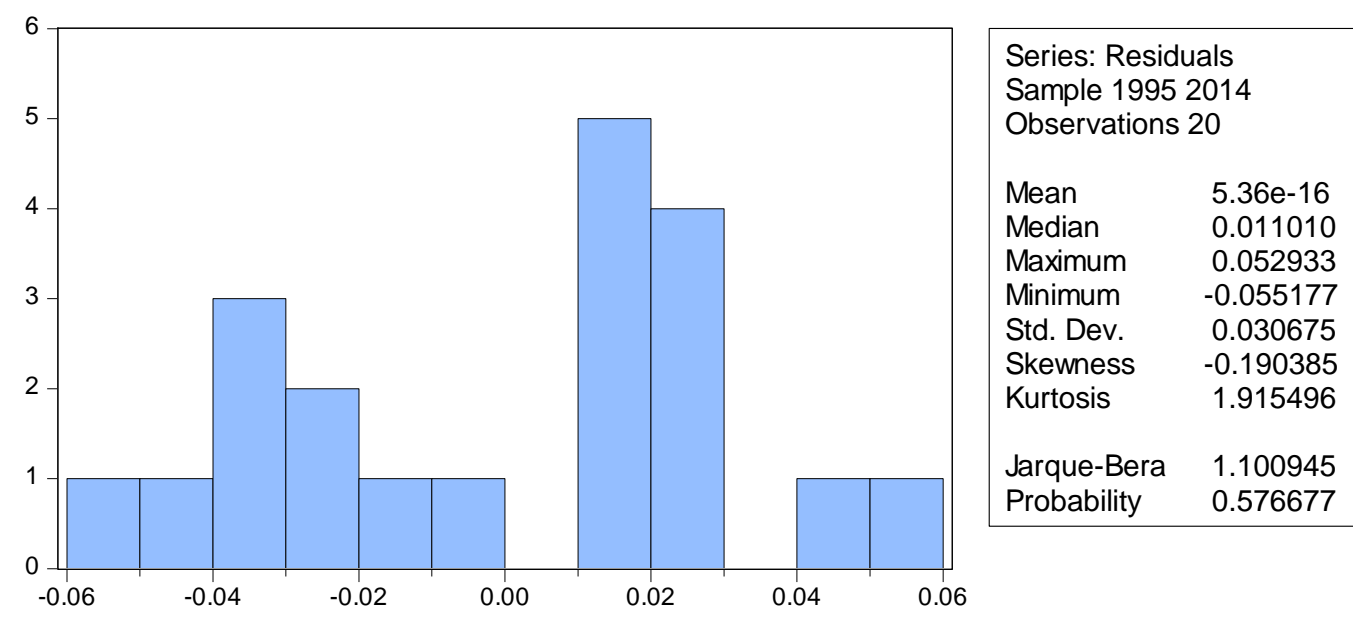

Berdasarkan Gambar 1 di atas diperoleh nilai probability J-B hitung sebesar 0,576677. Nilai ini lebih besar dari alpha 0,05 atau 0,576677 >0,05. Maka dapat disimpulkan bahwa data penelitian ini berdistribusi normal.

Tabel 2

Hasil Uji Multikolinearitas

\begin{tabular}{|l|l|l|l|}
\hline Variabel & Coefficient & Uncentered & Centered VIF \\
\hline
\end{tabular}


Al-Masharif: Jurnal Ilmu Ekonomi dan Keislaman

Volume 6 Nomor 1 Ed. Januari-Juni 2018 : hal. 106-127

\begin{tabular}{|c|c|c|c|}
\hline & Variance & VIF & \\
\hline C & 0.328845 & 5885.889 & NA \\
\hline Pertumbuhan Ekonomi & 0.001244 & 5715.324 & 1.674127 \\
\hline Kemiskinan & $3.66 \mathrm{E}-05$ & 4.946273 & 1.735670 \\
\hline Pengeluaran Pemerintah & $4.65 \mathrm{E}-08$ & 1.990217 & 1.057497 \\
\hline
\end{tabular}

Tabel 2 diatas menunjukkan nilai Variance Inflation Vactor (VIF) dari ketiga variabel adalah lebih kecil dari 10 atau 5, yakni nilai VIF pertumbuhan ekonomi sebesar 1.674127,nilai VIF kemiskinan sebesar 1.735670 dan nilai VIF pengeluaran pemerintah 1.057497. Maka data penelitian yang terdiri dari pertumbuhan ekonomi, kemiskinan dan pengeluaran pemerintah bebas dari multikolinieritas.

Tabel 3 Hasil Uji Heteroskedastisitas

\begin{tabular}{|c|c|c|c|}
\hline F-statistic & 0.724432 & Prob. F(3,16) & 0.5521 \\
\hline Obs*R-squared & 2.391747 & Prob. Chi-Square(3) & 0.4952 \\
\hline Scaled explained SS & 1.025223 & Prob. Chi-Square(3) & 0.7951 \\
\hline
\end{tabular}

Berdasarkan Tabel 3 diatas menunjukkan nilai prob. $F(3,16)$ adalah 0,5521 . Nilai tersebut lebih besar dari $0,05(0,5521>0,05)$. Artinya nilai $\mathrm{F}$ hitung lebih besar dari alpha maka Ho diterima atau tidak terjadi heterokedastisitas dalam penelitian ini.

Tabel 4 Hasil Uji Autokorelasi

\begin{tabular}{|c|c|l|c|}
\hline F-statistik & 0.645060 & Prob. F(2,14) & 0.5395 \\
\hline Obs*R-square $^{*} 1.687520$ & Prob. Chis-Squere(2) & 0.4301 \\
\hline
\end{tabular}

Berdasarkan tabel 4 Nilai probabilitas F hitung pada tabel di atas adalah 0,5395. Nilai ini lebih besar daripada nilai alpha 0,05 atau 0,5395 > 0,05. Maka Ho diterima atau tidak terjadi autokolerasi dalam penelitian ini. 


\section{FAKTOR-FAKTOR YANG MEMPENGARUHI INDEKS PEMBANGUNAN MANUSIA (IPM) DI PROVINSI SUMATERA UTARA TAHUN 1995-2014"}

Untuk mengetahui pengaruh pertumbuhan ekonomi, realisasi pengeluaran pendidikan, realisasi pengeluaran kesehatan terhadap indeks pembangunan manusia di provinsi Sumatera Utara digunakan Adapun sistem pengolahan data ini adalah dengan menggunakan software $e$-views 9 .

Tabel 4

Analisis Regresi Linier Berganda

\begin{tabular}{|c|c|c|c|c|}
\hline Variabel & Coefficient & Std. Error & t-Statistic & Prob. \\
\hline C & 3.362285 & 0.573450 & 5.863260 & 0.0000 \\
\hline Pertumbuhan Ekonomi & 0.056232 & 0.035265 & 1.594531 & 0.1304 \\
\hline Kemiskinan & -0.006374 & 0.006048 & -1.053935 & 0.3076 \\
\hline Pengeluaran Pemerintah & 0.000769 & 0.000216 & 3.565648 & 0.0026 \\
\hline
\end{tabular}

Berdasarkan hasil uji regresi pada Tabel 4.1 diatas, maka persamaan analisis regresi linier

berganda penelitian adalah:

$$
\begin{aligned}
& \mathrm{IPM}=\beta_{0}+\beta_{1} \mathrm{PE}+\beta_{2} \mathrm{TK}+\beta_{3} \mathrm{PP}+\mathrm{e} \\
& \mathrm{IPM}=3,362285+0,056232 \mathrm{PE}-0,006374 \mathrm{TK}+0,000769 \mathrm{PP}+\mathrm{e}
\end{aligned}
$$

Untuk mengetahui seberapa besar pengaruh variabel independen terhadap variabel dependennya, dapat dilihat pada tabel berikut :

Tabel 5

Hasil Uji Determinasi $\mathbf{R}^{2}$

\begin{tabular}{|l|r|l|r|}
\hline R-squared & 0.539971 & Mean dependent var & 4.274814 \\
\hline Adjusted R-squared & 0.453716 & S.D. dependent var & 0.045227 \\
\hline S.E. of regression & 0.033428 & Akaike info criterion & -3.782017 \\
\hline Sum squared resid & 0.017878 & Schwarz criterion & -3.582871 \\
\hline Log likelihood & 41.82017 & Hannan-Quinn criter. & -3.743142 \\
\hline F-statistic & 6.260144 & Durbin-Watson stat & 1.964019 \\
\hline Prob(F-statistic) & 0.005144 & & \\
\hline
\end{tabular}

Berdasarkan Tabel 4.7 diatas, nilai $R$-Square diperoleh sebesar 0.53997. Hal ini menunjukkan bahwa Indeks Pembangunan Manusia (IPM) mampu dijelaskan pertumbuhan ekonomi, kemiskinan, dan pengeluaran pemerintah sebesar 53,99 persen. Sedangkan sisanya sebesar 46,01 persen dipengaruhi oleh variabel lain diluar model. Hal ini berarti masih terdapat variabel lain yang mempengaruhi Indeks Pembangunan Manusia (IPM). 
Pengaruh Pertumbuhan Ekonomi terhadap Indeks Pembangunan Manusia (IPM)di

\section{Provinsi Sumatera Utara.}

Berdasarkan hasil regresi yang dilakukan dalam penelitian ini menunjukkan bahwa nilai koefisien pertumbuhan ekonomi sebesar 0,056232, artinya pertumbuhan ekonomi memiliki pengaruh positif terhadap Indeks Pembangunan Manusia (IPM). Jika pertumbuhan ekonomi meningkat 1 persen maka pertumbuhan ekonomi akan naik sebesar 0,056232. Adapun dengan menggunakan uji t pada tingkat signifikan 5 persen, pertumbuhan ekonomi memiliki nilai prob. t-test sebesar 0,1304 yang lebih besar dari 0,05. Hal ini menunjukkan jika pertumbuhan ekonomi tidak berpengaruh signifikan terhadap Indeks Pembangunan Manusia (IPM).Artinya setiap ada peningkatan pertumbuhan ekonomi tidak serta merta meningkatkan Indeks Pembangunan Manusia (IPM).

Pertumbuhan ekonomi tidak berpengaruh signifikan terhadap Indeks Pembangunan Manusia (IPM0 disebabkan karena masih banyak permasalahan pembangunan yang belum terpecahkan.Misalnya, kemiskinan yang masih cukup tinggi, dan distribusi pendapatan yang tidak merata. Hasil penelitian ini didukung oleh Robert M. Solow, di dalam buku yang berjudul "Pembangunan Ekonomi di dunia Ketiga Edisi Kedelapan", menyatakan bahwa pertumbuhan output bersumber dari satu atau lebih dari tiga faktor yaitu, kenaikan kuantitas dan kualitas tenaga kerja (melalui pertumbuhan jumlah penduduk dan perbaikan pendidikan), penambahan modal dan peningkatan teknologi. Sedangkan salah satu alat pengukur pembangunan kualitas dan kuantitas tenaga kerja adalah Indeks Pembangunan Manusia (IPM).

Hasil penelitian ini juga didukung oleh penelitian terdahulu Mochammad Yuli Arifin dengan judul "Pengaruh Pengeluaran Pemerintah Sektor kemiskinan, Pengeluaran Pemerintah Sektor Pendidikan dan Pertumbuhan Ekonomi terhadap Indeks Pembangunan Manusia Jawa 


\section{FAKTOR-FAKTOR YANG MEMPENGARUHI INDEKS \\ PEMBANGUNAN MANUSIA (IPM) DI PROVINSI \\ SUMATERA UTARA TAHUN 1995-2014"}

Timur 2006-2013".Dalam penelitian tersebut variabel pertumbuhan ekonomi berpengaruh positif dan tidak signifikan terhadap indeks pembangunan manusia di Jawa Timur tahun 2006-2013.Artinya, setiap kali terjadi peningkatan perekonomian tidak berpengaruh terhadap indeks pembangunan manusia.

\section{Pengaruh Kemiskinan terhadap Indeks Pembangunan Manusia (IPM) di Provinsi Sumatera Utara.}

Berdasarkan hasil regresi yang dilakukan dalam penelitian ini menunjukkan bahwa nilai koefisien kemiskinan sebesar -0,006374, artinya kemiskinan memiliki pengaruh negatif terhadap Indeks Pembangunan Manusia (IPM). Jika kemiskinan naik 1 persen maka variabel Indeks Pembangunan Manusia (IPM)akan mengalami penurunan sebesar 0,006374. Adapun dengan menggunakan uji t pada tingkat signifikan 5 persen, kemiskinan memiliki nilai prob. t-test sebesar 0,3076 yang lebih besar dari 0,05. Hal ini menunjukkan jika kemiskinan tidak berpengaruh signifikan terhadapIndeks Pembangunan Manusia (IPM).Artinya tingkat kemiskinan secara langsung tidak berpengaruh terhadap pencapaian Indeks Pembangunan Manusia (IPM).

Kemiskinan tidak berpengaruh signifikan terhadap Indeks Pembangunan Manusia (IPM) disebabkan oleh program-program pengentasan kemiskinan selama ini belum berjalan efektif, karena program kemiskinan ini masih sering salah sasaran.Misalnya, orang miskin yang tidak bisa membayar uang sekolah anaknya, malah mendapatkan bantuan beras miskin (raskin). Hasil penelitian ini didukung oleh Ragnar Nurkse di dalam buku yang berjudul "Ekonomi Pembangunan Edisi 5" dalam salah satu konsepnya, yaitu lingkaran kemiskinan (the vicious circle of poverty), dengan jelas mengungkapkan bahwa salah satu faktor penyebab timbulnya lingkaran setan kemiskinan adalah adanya hambatan dalam pembentukan modal. Lingkaran setan kemiskinan itu dapat didefinisikan sebagai suatu rangkaian kekuatan yang saling mempengaruhi satu sama lain sehingga menimbulkan suatu kondisi dimana 
sebuah negara (atau masyarakat dalam satu negara) akan tetap miskin dan akan mengalami banyak kesulitan dalam mencapai tingkat pembangunan yang lebih tinggi.

Hasil penelitian ini juga didukung oleh penelitian terdahulu Dedy Pudja Wardana dengan judul "Pengaruh Pembangunan ekonomi terhadap Pembangunan Manusia di Kalimantan Timur'.Dalam penelitian tersebut variabel kemiskinan berpengaruh negatif dan tidak signifikan terhadap indeks pembangunan manusia Jawa Timur tahun 2006-2013. Hasil ini menunjukkan bahwa tingkat kemiskinan tidak mempunyai efek atau pengaruh secara langsung terhadap masalah pencapaian pembangunan manusia melalui program-program pengentasan kemiskinan.

\section{Pengaruh Pengeluaran Pemerintah terhadap Indeks Pembangunan Manusia (IPM) di}

\section{Provinsi Sumatera Utara.}

Berdasarkan hasil regresi yang dilakukan dalam penelitian ini menunjukkan bahwa variabel pengeluaran pemerintah menunjukkan tanda positif dan signifikan terhadap Indeks Pembangunan Manusia (IPM).Nilai koefisien pengeluaran pemerintah sebesar 0.000769, artinya jika variabel pengeluaran pemerintah naik sebesar 1 persen maka Indeks Pembangunan Manusia (IPM) meningkat sebesar 0.007 persen.

Hasil penelitian ini sesuai dengan teori yang terdapat di dalam buku yang berjudul "Pembangunan Ekonomi di dunia Ketiga Edisi Kedelapan", dimana HDI menunjukkan bahwa kesenjangan dalam pendapatan lebih besar daripada kesenjangan dalam indikator pembangunan yang lain, paling tidak dalam indikator kesehatan dan pendidikan. Human Development Index (HDI) juga mengingatkan bahwa pembangunan yang dimaksud adalah pembangunan manusia dalam arti luas, bukan hanya dalam bentuk pendapatan yang lebih tinggi.Banyak negara, seperti sejumlah negara penghasil minyak yang berpendapatan tinggi, disebut sebagai negara yang mengalami “pertumbuhan tanpa pembangunan”. Kesehatan dan 


\section{FAKTOR-FAKTOR YANG MEMPENGARUHI INDEKS \\ PEMBANGUNAN MANUSIA (IPM) DI PROVINSI \\ SUMATERA UTARA TAHUN 1995-2014"}

pendidikan bukan hanya input fungsi produksi (seperti dalam perannnya sebagai komponen modal manusia) namun juga merupakan tujuan pembangunan yang fundamental.

Pendidikan dan kesehatan merupakan tujuan pembangunan yang mendasar, terlepas dari hal-hal yang lain, kedua hal itu merupakan hal yang penting.Kesehatan merupakan inti dari kesejahteraan, dan pendidikan adalah hal yang pokok untuk menggapai kehidupan yang memuaskan dan berharga, keduanya adalah hal yang fundamental untuk membentuk kapabilitas manusia yang lebih luas yang berada pada inti makna pembangunan.Sehingga dapat disimpulkan jika pengeluaran pemerintah (kesehatan dan pendidikan) baik atau meningkat, maka pembangunan manusia juga ikut baik atau mengalami peningkatan juga.

Hasil penelitian ini juga didukung oleh penelitian terdahulu Meylina Astri dengan judul "Pengaruh Pengeluaran Pemerintah Daerah pada Sektor Pendidikan dan Kesehatan terhadap Indeks Pembangunan Manusia di Indonesia".Dalam penelitian tersebut variabel pengeluaran pemerintah daerah pada sektor pendidikan dan kesehatan secara serempak memberikan pengaruh positif dan signifikan terhadapIndeks Pembangunan Manusia (IPM).

\section{KESIMPULAN}

Pertumbuhan ekonomi berpengaruh positif tetapi tidak signifikan terhadap tingkat Indeks Pembangunan Manusia (IPM) di Sumatera Utara dimana nilai probabilitas adalah sebesar 0,1304, nilai tersebut lebih besar dari taraf signifikansi 5 persen $(0,1304>0,05)$. Kemiskinan berpengaruh negatif tetapi tidak signifikan terhadap tingkat Indeks Pembangunan Manusia (IPM) di Sumatera Utara dimana nilai probabilitas adalah sebesar 0,3076, nilai tersebut lebih besar dari taraf signifikansi 5 persen $(0,3076>0,05)$. Pengeluaran pemerintah berpengaruh positif dan signifikan terhadap tingkat Indeks Pembangunan Manusia (IPM) di Sumatera Utara dimana nilai probababilitas adalah sebesar 0,0026, nilai tersebut lebih kecil dari taraf signifikan 5 persen $(0,0026<0,05)$. Pertumbuhan ekonomi, kemiskinan, dan pengeluaran pemerintah secara simultan memiliki pengaruh yang signifikan terhadap Indeks 
Pembangunan Manusia (IPM) di Provinsi Sumatera Utara dengan nilai F statistik $(0,005144$ < $0,05)$

\section{DAFTAR PUSTAKA}

Abdullah Zaky Al kaaf, Ekonomi dalam Perspektif Islam, Bandung: CV Pustaka Setia, 2002.

Badan Pusat Statistik, Indeks Pembangunan Manusia 2007-20o8. Jakarta: CV. Nario Sari, 2009.

Departemen Agama Islam RI, Musaf Al-Quran dan terjemahannya. Jakarta Timur: CV. Pustaka Al Kautsar. 2009.

Lincolin Arsyad, Ekonomi Pembangunan Edisi ke- 5. Yogyakarta: UPP STIM YKPN, 2010.

M. L. Jhingan, Ekonomi Pembangunan dan Perencanaan. Jakarta: Raja Grafindo, 1996.

Michael P. Todaro dan Stephen C. Smith. Pembangunan Ekonomi Di dunia Ketiga. Terjemahanoleh Haris Munandar, Puji A.L., Jilid 1. Edisi Kedelapan.Jakarta: Erlangga, 2003.

Muhammad. Metodologi Penelitian Ekonomi Islam: Pendekatan Kuantitatif (Dilengkapi dengan Contoh-contoh Aplikasi: Proposal Penelitian dan Laporannya). Jakarta: Rajawali Pers, 2008.

Sadono Sukirno. Ekonomi Pembangunan: Proses, Masalah dan Dasar Kebijakan. Jakarta: Kencana, 2014.

Said Sa'ad Marthon.Ekonomi Islam: Di Tengah Krisis Global. Jakarta: Zikrul, 2004. 


\section{FAKTOR-FAKTOR YANG MEMPENGARUHI INDEKS \\ PEMBANGUNAN MANUSIA (IPM) DI PROVINSI \\ SUMATERA UTARA TAHUN 1995-2014"}

Suparmoko, Keuangan Negara Dalam Teori dan Praktek Edisi 5, Yogyakarta:BPFE. 2000.

Setiawan dan Kusrini, Endah, Dwi. 2010. Ekonometrika, Yogyakarta : Andi.

Siregar, Syofian. 2014. Statistik Parametrik untuk Penelitian Kuantitatif, Jakarta : Bumi Aksara.

Sugiono dan Susanto, Agus. 2015. Cara Mudah Belajar SPSS dan Lisrel Teori Dan Aplikasi Untuk Analisis Data Penelitian, Bandung : Alfabeta. 